\title{
Curriculum Content Relevancy in Integration of ICTs in Kenya TVET Institutions in Readiness to Industry Needs
}

\author{
Tirus Muya Maina ${ }^{1, ~ *, ~ D a v i d ~ M . ~ K a h a n d o ~}{ }^{2}$, Charity Mweru Maina ${ }^{3}$ \\ ${ }^{1}$ School of Computing and Information Technology, Murang'a University of Technology, Murang'a, Kenya \\ ${ }^{2}$ School of Business and Management Studies, The Technical University of Kenya, Nairobi, Kenya \\ ${ }^{3}$ Library and Learning Resources Service, The Technical University of Kenya, Nairobi, Kenya
}

\section{Email address:}

tirus.maina@gmail.com (T. M. Maina)

${ }^{*}$ Corresponding author

\section{To cite this article:}

Tirus Muya Maina, David M. Kahando, Charity Mweru Maina. Curriculum Content Relevancy in Integration of ICTs in Kenya TVET Institutions in Readiness to Industry Needs. International Journal of Secondary Education. Vol. 4, No. 6, 2016, pp. 58-64. doi: 10.11648/j.ijsedu.20160406.11

Received: October 1, 2016; Accepted: November 10, 2016; Published: January 17, 2017

\begin{abstract}
The development of curricula content and their implementation is one of the key competences of instructors in the area of educational planning and practical training for Technical and Vocational Education and Training (TVET) institutions in Kenya. While much attention is being given to the development technologies that drive ICT integration in TVET, one of the most critical issues remains the curriculum content. The TVET sub-sector continues to be challenged by inflexible and outdated TVET curriculum, Mismatch between the skills learned and the skills demanded by industries, inadequate mechanism for quality assurance, Low participation of private sector in the curriculum design and development. The objective of the study was to evaluate the relevancy of the curricula content in achieving integration of ICTs in TVET institutions in Kenya with specific reference to Michuki and Thika Technical Training Institute in Murang'a and Kiambu County respectively. The research adopted quantitative research approach and use probability sampling which is commonly associated with Survey-based research. The study's main data collection tool was a structured questionnaire. Descriptive statistics was used, correlation and regression analysis to test the relationship and strength of association between curriculum content and integration of ICTs in Kenya TVET. From regression analysis, since the p-value is 0 , the relationship between effectively integration and Curriculum Content is significant, the correlation coefficient, $\mathrm{R}$, is 0.776 . Therefore, Effective Integration is positively correlated with Curriculum Content and the relationship is very strong. The study recommended that; ICT should be integrated in curriculum courses available in TVET institutions in Kenya. TVET Authority and Kenya Institute of curriculum development (KICD) with involvement of stakeholders should promote access and relevance of TVET training courses. The review should be within the framework of the overall national socio-economic development plans and policies that reflects the needs of industry and the labor market.
\end{abstract}

Keywords: ICT, TVET, Curriculum, Integration, Kenya

\section{Introduction}

The development of curricula and their implementation is one of the key competences of instructor in the area of educational planning and practical training for Technical and Vocational Education and Training (TVET) institutions and industry [1]. According to [2], the TVET sub-sector continues to be challenged by inflexible and outdated TVET curriculum content, Mismatch between the skills learned and the skills demanded by industries, inadequate mechanism for quality assurance, Low participation of private sector in the curriculum design and development. While much attention is being given to the development technologies that drive ICT integration in TVET, one of the most critical issues remains the curriculum content.

The most pressing challenge to the effective integration of ICTs in TVET according to [3] is curriculum content. [4] also noted that current impediment to the further growth and 
diffusion of more advanced systems in all parts of the world is the unavailability of relevant, well-designed instructional content particularly in the TVET education subsector. [5] Argued that TVET institutions need to restructure their programmes to be responsive to the needs of the job market, especially the industry. To achieve this goal, TVET curricula must focus on outcomes in terms of the skills, knowledge and attitudes required industry.

[6] Revealed that both formal and non-formal TVET lacked an effective linkage between training and the world of work especially in the ICT Sector, because of its lack of coherent mode, practical skills training which does not produce the requisite skills for the job market. The main curriculum for TVET education in Kenya is developed by the Kenya Institute of Curriculum Development (KICD). The function of KICD include implementation of the policies relating to curriculum development in basic and tertiary education and training, Develop, review and approve programmes, curricula and curriculum support materials that meet international standards for TVET subsector among others [7].

In Kenya, the professional national certification bodies such as the Kenya National Examination Council (KNEC); Kenya Accountants and Secretaries National Examinations Board (KASNEB) are Involved in the assessment and certification. Challenges are factors that hinder integration of ICTs in teaching and learning activities in various subjects in TVETs or any condition that makes it difficult to progress or integrate ICT by instructors in the classroom [8]. Various scholars classify challenges into extrinsic and intrinsic categories. Extrinsic challenges are first order challenges that include access, time, support, resources and training. Intrinsic are second order challenges and include attitudes, beliefs, practices and resistance [9].

Challenges range from instructor-level to institutional level [8]. According to BECTA, instructor level challenges include lack of time, lack of confidence, lack of competence and resistance to change. Institution level challenges include lack of effective training, lack of access to resource, time, and technical support among others. [10] Cited that the current TVET curriculum in Kenya is weak and not flexible enough to meet the technological changes and diverse needs of different clients. [11] Noted that the quality of TVET graduates has declined in recent years due to poor instructional methods, outmoded/inadequate training equipment and lack of meaningful work experience and supervision during attachment. The graduates of TVET have experienced technology shock when they finally enter the industry due to The lack of ICT focus in the curriculum and does not provide standards or guidelines for ICT usage in course delivery thus has resulted in fragmented efforts in the use of ICT for instruction thus formed the basis of this research.

The Research objectives
The objective of the study was to evaluate the relevancy of the curriculum content in achieving integration of ICTs in TVET institutions in Kenya in readiness to industry needs.

The study was guided by the following specific objectives:

i. To determine the Relevance of ICT content in the curriculum to the courses

ii. To evaluate the curriculum content linkage between training and the world of work

iii. To Evaluate the Extent ICT has been integrated into the educational and learning processes

iv. To find out Teachers Incorporation of ICTs in their instruction and curricula

$\mathrm{v}$. To demine the relationship between curriculum content and Effective Integration of ICTs in TVET in Kenya

\section{Research Methodology}

The study adopted quantitative approach and crosssectional Survey Research design. Research design is carried out at a just one point in time and popularly used in education [12]. The study was confined to Michuki Technical Training institute in Murang'a County and Thika Technical Training Institute in Kiambu County. Both Technical Training Institute operates under the Education Act and TVETA as stipulated in the laws of Kenya.

The study sample was drawn from a population of 195 consisting of Management staff, which include Board of Management and Principal. Administrative staff include Deputy Principal, Head of Departments, Head of Sections and Administration Assistant, teaching staff and technical staff The data was collected using structured questionnaire properly formatted with both open ended and closed questions adopting a five-point Likert scale with a view to uniformed information [13, 12 and 14].

To get sample size from the target population Taro Yamane simplified formula was adopted, it provided a simplified formula to calculate sample size. It's a random sampling technique formula to estimate sampling size and is used to calculate the sample size (n) given the population size $(\mathrm{N})$ and a margin of error $(\varepsilon)$ at 95 percent confidence level [18]. The sample size of 150 respondents was represented as follows; 13 Management staff, 20 Administrative staff, 106 Teaching staff and 11 Technical staff

\section{Discussion and Findinds}

\subsection{The Relevance of ICT Content in the Curriculum to the Courses}

The study sought to find out The ICT content in the curriculum is relevant to the course available in selected TVET institution in Kiambu and Murang'a County, Kenya. 
Table 1. The Relevance of ICT content in the curriculum to the courses.

\begin{tabular}{lllllll}
\hline & \multicolumn{4}{l}{ The ICT content in the curriculum is relevant to the course available in the institution } \\
\cline { 3 - 6 } & & Strongly Disagree & Disagree & Undecided & Agree & \\
\hline \multirow{2}{*}{ Institutions } & Count & 9 & 68 & 15 & 21 & 113 \\
& $\%$ within Institution & $8.0 \%$ & $60.2 \%$ & $13.3 \%$ & $18.6 \%$ & $100.0 \%$ \\
\hline
\end{tabular}

Source: Author Data (2015)

The study findings from table 1 revealed that $21(18.6 \%)$ of the respondents were in support that the ICT content in the curriculum is relevant to the course available in the institution. This can be inferred that the respondents are Computer specific courses in the ICT departments were the ICT contents in the curriculum is relevant to the courses. [15] argued that in Kenya and globally the use of ICT in TVET institutions is for tutoring in computer science and computer literacy.

Further the findings revealed that $68.2 \%$ of the respondents were in agreement with [15] that The ICT content in the curriculum is not relevant to the course available in the institution. This can be concluded that the
TVET curriculum content has not been reviewed thus outdated which doesn't incorporate new emerging technologies such ICT's. The curricula developers need to continuously restructure their courses to be responsive to the needs of emerging technologies that will match graduate skills with the fast ever changing industry needs

\subsection{ICT Integration in TVET Curriculum}

The study sought to find out if ICT has been integrated in curriculum courses available in selected TVET institution in Kiambu and Murang'a County, Kenya.

Table 2. ICT Integration in TVET curriculum.

\begin{tabular}{lllllll}
\hline & & \multicolumn{4}{l}{ ICT has been integrated in curriculum courses available in the institution } & \multirow{2}{*}{ Total } \\
\cline { 3 - 6 } & & Strongly Disagree & Disagree & Undecided & Agree & \\
\hline \multirow{2}{*}{ Institutions } & Count & 15 & 80 & 5 & 13 & 113 \\
& $\%$ within Institution & $13.3 \%$ & $70.8 \%$ & $4.4 \%$ & $11.5 \%$ & $100.0 \%$ \\
\hline
\end{tabular}

Source: Author Data (2015)

From The results from table 2, $84.1 \%$ of the respondents indicated that ICT has not been integrated in curriculum courses available in their respective institutions. This can be inferred that the curriculum developers have not integrated ICT into the courses offered by the TVET institution.

[10] concurred with findings that ICT is widely taught as a subject in a majority of the institutions however the curriculum does not provide standards or guidelines for ICT usage in course delivery, the focus is on the techno-centric skills and basic ICT literacy. While $11.5 \%$ of the respondent are in favor that ICT has been integrated into the curriculum course it can be inferred that this respondents were instructor who instruct ICT specific curriculum or computer based courses.

\subsection{ICT has been Integrated into the Educational and Learning Processes}

The study sought to find out ICT has been integrated into the educational and learning processes in the institution in selected TVET institution in Kiambu and Murang'a County, Kenya.

Table 3. ICT has been integrated into the educational and learning processes.

\begin{tabular}{llllll}
\hline & & \multicolumn{3}{l}{ ICT has been integrated into the educational and learning processes } & \multirow{2}{*}{ Total } \\
\cline { 3 - 5 } & & Disagree & Undecided & Agree & \\
\hline \multirow{2}{*}{ Institutions } & Count & 80 & 11 & 22 & 113 \\
& $\%$ within Institution & $70.8 \%$ & $9.7 \%$ & $19.5 \%$ & $100.0 \%$ \\
\hline
\end{tabular}

Source: Author Data (2015)

From the findings of table 3 shows that 80 (70.8\%) of the respondent indicated that ICT has not been integrated into the educational and learning process in the institutions, while $22(19.5 \%)$ agreed $11(9.7 \%)$ were undecided. This can be deduced that the institution have not fully integrated into educational and learning process. This can be attributed by the fact that instructors from their previous technical training institutions teachers have not been trained on the new pedagogical skills to take full advantage of ICTs to enhance educational and learning process. Also it can be deduced that those who have implemented ICTs in teaching and learning are staff for ICTs Department who teach ICT related courses.

[16] Argued that there is low level of ICT integration into the educational and learning processes in the TVET and is attributed to the fact that teachers lack skills or experience challenge to integrate ICT into classroom teaching. Lack of technical support in ICT integration, lack of dedicated time, lack of confidence, lack of competence and resistance to change in education could be other challenge to many instructor [8]. 


\subsection{Instructors have Incorporated ICTs in Their Instruction and Curricula}

The study sought to find out instructor have incorporated
ICTs in their instruction and curricula in the institution in selected TVET institution in Kiambu and Murang'a County, Kenya.

Table 4. Instructors have Incorporated ICTs in their instruction and curricula.

\begin{tabular}{|c|c|c|c|c|c|c|}
\hline & & \multicolumn{4}{|c|}{ Instructors have Incorporated ICTs in their instruction and curricula } & \multirow{2}{*}{ Total } \\
\hline & & Strongly Disagree & Disagree & Undecided & Agree & \\
\hline \multirow{2}{*}{ Institutions } & Count & 6 & 52 & 16 & 39 & 113 \\
\hline & $\%$ within Institution & $5.3 \%$ & $46.0 \%$ & $14.2 \%$ & $34.5 \%$ & $100.0 \%$ \\
\hline
\end{tabular}

Source: Author Data (2015)

The findings from table 4 established a dismal $34.5 \%$ of the respondents have incorporated ICTs in their instruction and curricula in classroom, workshop and laboratories. [16] Was in agreement with the findings that ICTs are currently being used widely to aid education in many developing countries, and it appears that there is increasing demand for their use in education by policymakers and parents in developing countries.

However $51.3 \%$ of the respondent indicated that instructors have not incorporated ICTs in their instruction and curricula in classroom, workshop and laboratories. This can be attributed to the fact that instructors lack skills, lack of time to train, lack of confidence, lack of competence and resistance to change to integrate ICT into classroom teaching as supported by [16] [8]. This can also be deduced that the specific institutions management have not embraced information and communication technologies in their institution that aid tutors to use this technologies.

\subsection{The Current Curriculum Is Inflexible and Out Dated}

The study sought to find out the current curriculum content is inflexible and out dated to meet the ICT technological changes in selected TVET institution in Kiambu and Murang'a County, Kenya.

Table 5. The current curriculum is inflexible and out dated.

\begin{tabular}{|c|c|c|c|c|c|c|}
\hline & & \multicolumn{4}{|c|}{ The current curriculum is inflexible and out dated to meet the ICT technological changes } & \multirow{2}{*}{ Total } \\
\hline & & Disagree & Undecided & Agree & Strongly Agree & \\
\hline \multirow{2}{*}{ Institutions } & Count & 22 & 7 & 62 & 22 & 113 \\
\hline & $\%$ within Institution & $19.5 \%$ & $6.2 \%$ & $54.9 \%$ & $19.5 \%$ & $100.0 \%$ \\
\hline
\end{tabular}

Source: Author Data (2015)

The results from table 5 revealed that $74.4 . \%$ of the respondent indicated that the current curriculum is inflexible and out dated to meet the ICT technological changes. This can be deduced that the curriculum developer and policy makers have not updated the curriculum to match with the fast ICT technological changes especially in non ICT courses. In Support [2] and [10] confirmed that the TVET sub-sector in Kenya continues to be challenged by Inflexible, outdated and weak TVET curriculum, Mismatch between the skills learned and the skills demanded by industries, inadequate mechanism for quality assurance, Low participation of private sector in the curriculum design and development.

Using outdated curriculum is a failure by the government to set strategies that would link education and training to specific growth paths and prioritizing skills and proficiencies that would lead to a more competitive edge. Such strategies have been used to create newly industrialized countries like Korea and Japan [17].

The current curriculum is neither inflexible or out dated to meet the ICT technological changes as supported by $19.5 \%$ of the respondent. This can be inferred that most probably this are ICT based and relatively new courses thus the curriculum might have incorporated the current ICTs.

\subsection{Linkage Between Training and the World of Work}

The study sought to find out whether the curriculum content lacks an effective linkage between training and the world of work especially in the ICT Sector in selected TVET institution in Kiambu and Murang'a County, Kenya.

Table 6. The TVET Curriculum content linkage.

\begin{tabular}{|c|c|c|c|c|c|c|}
\hline & & \multicolumn{4}{|c|}{$\begin{array}{l}\text { The TVET curriculum content lacks an effective linkage between training and the world of work } \\
\text { especially in the ICT Sector }\end{array}$} & \multirow[t]{2}{*}{ Total } \\
\hline & & Disagree & Undecided & Agree & Strongly Agree & \\
\hline \multirow{2}{*}{ Institutions } & Count & 10 & 9 & 77 & 17 & 113 \\
\hline & $\%$ within Institution & $8.8 \%$ & $8.0 \%$ & $68.1 \%$ & $15.0 \%$ & $100.0 \%$ \\
\hline
\end{tabular}

Source: Author Data (2015) 
From the findings $83.1 \%$ of the respondent confirmed that The TVET curriculum content lacks an effective linkage between training and the world of work especially in the ICT Sector. This can be attributed due to inflexible and outdated curriculum used by teachers and learners in the institution and also that the curriculum developer don't console the industry stakeholders in curriculum developer.

Studies by [6] supported the findings that both formal and non-formal TVET lacked an effective linkage between training and the world of work especially in the ICT Sector. [16] Further noted that because of its lack of coherent mode, practical skills training which does not produce the requisite skills for the job market. It can also be inferred that the $8.8 \%$ of the respondent who had the opinion that The TVET content and curriculum has an effective linkage between training and the world of work especially in the ICT Sector are those who are in the ICT department and their course is relatively new in the market.

[5] Proposed that TVET institutions need to restructure their courses to be responsive to the needs of the job market, especially the industry. To achieve this goal, TVET curricula must focus on outcomes in terms of the skills, knowledge and attitudes required industry. That is, TVET provision should be responsive to the demands of industry.

\subsection{The Digitalization of Curriculum and Content}

The study sought to find out that the current curriculum content exist in digital format in the selected TVET institution in Kiambu and Murang'a County, Kenya.

Table 7. The digitalization of curriculum and Content.

\begin{tabular}{|c|c|c|c|c|c|c|}
\hline & & \multicolumn{4}{|c|}{ The current curriculum and Content exist in digital format (soft copy) } & \multirow{2}{*}{ Total } \\
\hline & & Strongly Disagree & Disagree & Undecided & Agree & \\
\hline \multirow{2}{*}{ Institutions } & Count & 23 & 77 & 6 & 7 & 113 \\
\hline & $\%$ within Institution & $20.4 \%$ & $68.1 \%$ & $5.3 \%$ & $6.2 \%$ & $100.0 \%$ \\
\hline
\end{tabular}

Source: Author Data (2015)

From the finding in table $7,6.2 \%$ of the respondent revealed that the current curriculum content exist in digital format (soft copy). Further it clearly shows that the current curriculum and Content doesn't exist in digital format as indicated by $88.5 \%$ of the respondents this can be inferred that the curriculum developer and policy makers have not digitalized the curriculum to be used in teaching and learning in TVET institution this was confirmed [18] on the Digitalization of the curriculum at different levels of education to enhance e-teaching and e-learning this includes TVET curricula.

\subsection{The Access and Use of E-Resources}

The study sought to find out that the institution have access and use E-Resources including E-books, E-journals in the Library in selected TVET institution in Kiambu and Murang'a County, Kenya.

Table 8. The Access and use E-Resources.

\begin{tabular}{|c|c|c|c|c|c|}
\hline & & \multicolumn{3}{|c|}{ The institution have access and use E-Resources including E-books, E-journals in the Library } & \multirow{2}{*}{ Total } \\
\hline & & Strongly Disagree & Disagree & Undecided & \\
\hline \multirow{2}{*}{ Institutions } & Count & 47 & 50 & 16 & 113 \\
\hline & $\%$ within Institution & $41.6 \%$ & $44.2 \%$ & $14.2 \%$ & $100.0 \%$ \\
\hline
\end{tabular}

Source: Author Data (2015)

The findings in table 8 above $85.6 \%$ of the respondent indicated that the institution don't have access and use EResources including E-books, E-journals in the Library for the courses offered. This can be deduced that the institutions have not subscribed to the Educational online E-Resources, E-journals and E-Library and that institutional management are reluctant to allocate adequate funds or are skeptical on the new technologies.

\subsection{Effect of Curriculum Content on Effective Integration of ICTs in TVET in Kenya}

The study sought to establish the relationship between curriculum content and Integration of ICTs by using simple regression.
Table 9. Content and Curriculum Correlation Model Summary.

\begin{tabular}{lllll}
\hline Model & R & R Square & $\begin{array}{l}\text { Adjusted R } \\
\text { Square }\end{array}$ & $\begin{array}{l}\text { Std. Error of } \\
\text { the Estimate }\end{array}$ \\
\hline 1 & $.776^{\mathrm{a}}$ & .602 & .598 & .460 \\
\hline
\end{tabular}

a. Predictors: (Constant), Content and Curriculum Source: Author Data (2015)

This table 9 provides the Pearson's $\mathrm{R}$ and $\mathrm{R}^{2}$ value. The $\mathrm{R}$ value is 0.776 , which represents a high degree of correlation. The $\mathrm{R}^{2}$ value indicates how much of the dependent variable Effectively Integration can be explained by the independent variable, content and curriculum. In this case, $\mathrm{R}^{2}=0.602$ which means that $60.2 \%$ of the variation in effective integration of ICT is explained by the variation of in content and curriculum. 
Table 10. Content and Curriculum ANOVA Table.

\begin{tabular}{lllllll}
\hline \multirow{2}{*}{ Model } & $\begin{array}{l}\text { Sum of } \\
\text { Squares }\end{array}$ & df & $\begin{array}{l}\text { Mean } \\
\text { Square }\end{array}$ & F & Sig. \\
\hline \multirow{3}{*}{$1 \quad$ Regression } & 35.578 & 1 & 35.578 & 167.915 & $.000^{\text {b }}$ \\
& Residual & 23.519 & 111 & .212 & & \\
\cline { 2 - 4 } & Total & 59.097 & 112 & & & \\
\hline
\end{tabular}

a. Dependent Variable: Effectively Integration

b. Predictors: (Constant), Content and Curriculum

Source: Author Data (2015)
The ANOVA table 10 indicates that the regression model predicts the outcome variable significantly well. This indicates the statistical significance of the regression model that was applied since $\mathrm{p}<0.00$, which is less than 0.05 , and indicates that, overall, the model applied can statistically significantly predict the outcome variable.

Table 11. Curriculum Content Coefficients Table.

\begin{tabular}{llllll}
\hline \multirow{2}{*}{ Model } & & \multicolumn{2}{c}{ Unstandardized Coefficients } & \multicolumn{2}{l}{ Standardized Coefficients } \\
\cline { 3 - 5 } & & B & Std. Error & Beta & Sig. \\
\hline \multirow{2}{*}{1} & (Constant) & .215 & .309 & & .695 \\
& Content and Curriculum & .937 & .072 & .776 & 12.958 \\
\hline
\end{tabular}

a. Dependent Variable: Effective Integration

Source: Author Data (2015)

The table 11Coefficients provides us with information on each predictor variable. This gives us the information we need to predict Effectively Integration from Curriculum Content. The constant and Effective Integration contribute significantly to the model thus can present the regression equation as:

Effective Integration $=0.215+0.937$ (Curriculum Content)

\section{Conclusion}

The results revealed that ICT has not been integrated in curriculum and it's not relevant courses available in the institutions. The current curriculum is inflexible and out dated to meet the ICT technological changes and lacks effective linkage between training and the world of work especially in the ICT Sector. Also it can be concluded that the current curriculum content doesn't exist in digital format and institution don't have access and use E-Resources including E-books, E-journals in the Library for the course offered. This can be deduced that the institutions have not subscribed to the Educational online E-Resources, E-journals and E-Library.

From regression analysis, since the p-value is 0 , the relationship between effectively integration and Curriculum Content is significant, the correlation coefficient, $\mathrm{R}$, is 0.776 . Therefore, Effective Integration is positively correlated with Curriculum Content and the relationship is very strong.

\section{Recommendation}

The Kenya TVET authority in conjunction with KICD to Revise TVET curriculum and content so that it reflects the technological needs of industry and the labor market. This can be done by Ensuring that TVET offers ICT competence based skills that reflects needed in the informal sector labor market, and in particular that it contributes to the increased productivity and earnings of this important sector in the Kenyan economy. The Government should endeavor Involvement of ICT stakeholders in the development of a national skills training strategy for the TVETs. The establishment of mechanisms and appropriate incentives to promote private sector investments in the development of TVET for increased access and also Digitalization of the curriculum and learning material at different levels of education to enhance e-teaching and elearning this includes TVET curricula.

\section{References}

[1] Rauner, "TVET Curriculum Development and Delivery," Institute Technology and Education, Germany, 2004.

[2] Republic of Kenya, "Kenya Education Sector Support Programme 2005 - 2010," Gorvement Press, Nairobi, 2005.

[3] B. Kotsik, "ICT application in TVET," in International handbook of education for the changing world of work, Springer Science \& Business Media B. V, 2009.

[4] G. Stevens, "Distance learning for Technical and Vocational Education in Sub-Sahara Africa," 2001. [Online]. Available: http://www.gtz.de/wbf/bibliothek/ detail.asp?number=1431. [Accessed 22 November 2012].

[5] G. Reddan and G. Harrison, "Restructuring the bachelor of exercise science degree to meet industry," Asia-Pacific Journal of Cooperative Education, vol. 11, no. 1, pp. 13-25, 2010.

[6] R. Islam and A. Mia, "The role of education for rural population transformation in Bangladesh," Asia-Pacific Journal of Cooperative Education, vol. 8, no. 1, pp. 1-21, 2007.

[7] Republic of Kenya, "The Technical and Vocational Education and Training Act," Government Printer, Nairobi, 2013.

[8] BECTA, "What is Whole-School ICT Policy?," 23 June 2012. [Online]. Available: http://www.becta.org.uk/technology/infosheets/html/itpolicy.html.

[9] P. E. Ertmer, "Examining teachers ${ }^{\text {ee }}$ beliefs about the role of technology in the elementary classroom," Journal for Research on Computing in Education, vol. 32, no. 1, pp. 5472, 1999. 
[10] J. Nyerere, "Education and Training (TVET)Sector Mapping in Kenya," Dutch Schokland TVET programme, 2009.

[11] B. G. Hailu, "Factors Affecting the Implementation of Technical and Vocational Education and Training in Selected Public Institutions of Southern Zone of Tigray," Addis Ababa, 2011.

[12] J. W. Creswell, Educational research: planning, conducting, and evaluating quantitative and qualitative research, Boston: Pearson Education, Inc, 2012.

[13] J. Wolf, "Self-administered questionnaire," in Encyclopedia of survey research methods, Thousand Oaks, 2008, pp. 804-805.

[14] A. Rubin and E. R. Babbie, Research Methods for Social Work, 6th ed., Belmont, CA: Thomson Brooks/Cole, 2008.

[15] M. Hooker, E. Mwiyeria, S. Waweru, M. Ocharo, R. Bassi and L. Palmer, "TVET ICT baseline survey. TVET Institutions in Kenya," MOHEST \& GESCI, Nairobi, 2011.

[16] M. Wagner, K. Kutash, A. J. Duchnowski, M. H. Epstein and W. C. Sumi, "Th e children and youth we serve: A national picture of the characteristics of students with emotional disturbances receiving special education," Journal of Emotional and Behavioral Disorders, vol. 13, no. 2, pp. 7996, 2005.

[17] S. W. Ngure, "stakeholders' perceptions of technical, vocational education and training: the case of kenyan micro and small enterprises in the motor vehicle service and repair industry," Edith Cowan University, 2013.

[18] G. D. Israel, "Determining Sample Size," University of Florida IFAS Extension Service, June 2013. [Online]. Available: http://edis.ifas.ufl.edu/pd006. [Accessed 15 January 2015].

[19] Republic of Kenya, "The Kenya Institute of Curriculum Development Act, 2013," GOVERNMENT PRINTER, Nairobi, 2013.

[20] B. G. G. Hailu, "Factors Affecting the Implementation of Technical and Vocational Education and Training in Selected Public Institutions of Southern Zone of Tigray," Addis Ababa, 2011. 